\title{
Effect of feeding calcareous marine algae to Holstein cows prepartum or postpartum on serum metabolites and performance
}

\author{
Z. Wu, ${ }^{* 1}$ J. K. Bernard, ${ }^{* 2}$ and S. J. Taylort \\ *Department of Animal and Dairy Science, University of Georgia, Tifton 31793 \\ †Celtic Sea Minerals, Marigot Ltd., Cork, Ireland
}

\begin{abstract}
Thirty-six multiparous Holstein cows and 12 springing heifers were used in a 9-wk randomized design trial to determine the response of cows fed calcareous marine algae (CMA) beginning 3 wk prepartum or after parturition through 6 wk postpartum on dry matter intake (DMI), blood and urine metabolites, and milk yield and composition. Within parity and expected calving date, cows were assigned randomly to 1 of 4 treatments with a $2 \times 2$ factorial arrangement. Prepartum diets were supplemented with calcium carbonate $(\mathrm{CON})$ or $50 \mathrm{~g} / \mathrm{d}$ of CMA with a resulting dietary cation-anion difference of -5.17 and $-3.99 \mathrm{mEq} / 100 \mathrm{~g}$, respectively. Postpartum diets were formulated to provide either $317 \mathrm{~g} / \mathrm{d}$ of sodium bicarbonate and calcium carbonate $(\mathrm{NBC})$ or $100 \mathrm{~g} / \mathrm{d}$ of CMA, providing a dietary cation-anion difference of 35.58 and $15.64 \mathrm{mEq} / 100 \mathrm{~g}$, based on $25 \mathrm{~kg} / \mathrm{d}$ of DMI, respectively. No differences were observed in prepartum DMI or postpartum DMI, milk yield, percentage of milk fat, protein, lactose, and solids-not fat among treatments. Milk protein yield was higher for cows fed CMA prepartum compared with CON. Interactions of prepartum treatment and week were observed for yield of milk fat and energy-corrected milk because of higher yields for cows fed CMA during wk 2 and 6 compared with CON. Serum Na concentrations were greater for cows fed CON prepartum or NBC postpartum compared with CMA. Postpartum urinary concentrations of $\mathrm{Na}$ exhibited an interaction among treatments and were higher for CON-NBC and CMANBC compared with CON-CMA and CMA-CMA. Similar interactions of treatments were also observed for serum urea $\mathrm{N}$ and creatinine postpartum. Postpartum urinary $\mathrm{K}$ concentrations were higher for cows fed CMA postpartum compared with NBC. Results of this trial indicate that feeding cows CMA prepartum does
\end{abstract}

Received August 5, 2014.

Accepted March 26, 2015.

${ }^{1}$ Current address: Philbro Animal Health Corp., 300 Frank W. Burr Blvd., Ste 21. Teaneck, NJ 07666-6712.

${ }^{2}$ Corresponding author: jbernard@uga.edu not affect DMI or serum metabolites prepartum, but does support higher milk protein yield. Performance and serum metabolite concentrations of cows fed CMA postpartum were comparable with that of cows fed NBC, except for changes in serum and urinary concentration of $\mathrm{Na}$, which was a function of dietary $\mathrm{Na}$ intake.

Key words: dietary cation-anion difference, milk yield, milk composition

\section{INTRODUCTION}

Calcareous marine algae (CMA; Calmin, Celtic Sea Minerals, Ireland) is produced from Lithothamnium species and contains (DM basis) $30 \% \mathrm{Ca}, 0.5 \% \mathrm{P}, 6.0 \%$ $\mathrm{Mg}$, and $0.1 \% \mathrm{~K}$ along with numerous trace minerals. The minerals are readily available and have been reported to support improved bone formation (Aslam et al., 2010) and to improve bone turnover in postmenopausal women (Slevin et al., 2014). Transition cows are highly susceptible to periparturient disease due to the tremendous physiological adaptations during that period. Milk fever or hypocalcaemia resulting from low blood Ca concentrations around parturition are economically important due to lower milk yield. Curtis et al. (1983, 1985) reported that cows diagnosed with clinical milk fever are at greater risk for developing other disorders, such as dystocia, retained fetal placenta, ketosis, or coliform mastitis. Feeding anionic diets with supplemental $\mathrm{Ca}$ prepartum has been shown to reduce clinical and subclinical hypocalcaemia (Block, 1984; Oetzel et al., 1988; Goff et al., 1991). We hypothesized that feeding supplemental CMA prepartum would provide a highly available source of $\mathrm{Ca}$, which would help maintain desirable $\mathrm{Ca}$ balance at and immediately after parturition compared with calcium carbonate when included in diets formulated to provide a negative DCAD.

Cationic diets are recommended postpartum to prevent rumen acidosis and further improve animal performance postpartum (West et al., 1991, 1992; Hu and Murphy, 2004). It has been proposed that CMA could be used as a rumen buffer, but in vitro results 
suggest that CMA was not as effective as sodium bicarbonate-based acid buffering capacity in rumen fluid, but worked well when a blend of CMA and sodium bicarbonate was used (Calitz, 2009; Mesgaran et al., 2013). When included in diets that would be expected to lower ruminal $\mathrm{pH}$, Beya (2007) reported that ruminal $\mathrm{pH}$ did not drop as sharply and suggested that because the minerals contained in CMA are slowly released the buffering effect was sustained longer.

Data are lacking from controlled studies to determine the effects of feeding CMA to lactating dairy cows. Currently no data are available to evaluate whether there are positive effects of feeding CMA beginning prepartum compared with waiting until postpartum. The objective of our study was to evaluate the effects of feeding CMA and time to begin feeding on DMI, blood and urine metabolites, and postpartum milk yield and composition.

\section{MATERIALS AND METHODS}

Thirty-six Holstein cows and 12 springing heifers were used in a randomized trial with a $2 \times 2$ factorial arrangement of treatments beginning either 3 wk prepartum or after parturition through 6 wk postpartum. This provided 12 animals on each of the 4 treatment combinations: prepartum control diet $(\mathbf{C O N})$-supplemental sodium bicarbonate (postpartum control diet; NBC), CON-CMA, CMA-NBC, and CMA-CMA. The supplemental rates of CMA were $50 \mathrm{~g} / \mathrm{d}$ prepartum and $100 \mathrm{~g} / \mathrm{d}$ postpartum according to the manufactures recommendations (Table 1). The CMA contained (DM basis) $30.00 \% \mathrm{Ca}, 0.05 \% \mathrm{P}, 6.00 \% \mathrm{Mg}$, and $0.70 \% \mathrm{~K}$ and replaced a portion of the calcium carbonate and magnesium oxide in CON. The NBC contained 317 $\mathrm{g} / \mathrm{d}$ of sodium bicarbonate and calcium carbonate to equalize Ca concentrations. Within parity and expected calving date, cows were assigned randomly to 1 of the 4 treatments before beginning the trial. All protocols were approved by the University of Georgia Institutional Animal Care and Use Committee.

Animals were trained to eat behind Calan doors (American Calan Inc., Northwood, NH) before beginning the trial. Cows were housed in a 4-row freestall barn with supplemental evaporative cooling provided by fans and misters and were allowed free access to a grassed exercise lot. At calving, cows were moved to grassed lot or a boxstall and returned to the freestall area after calving. Cows were fed once daily in amounts to provide a minimum of $5 \%$ refusal and had free access to water. The amount of feed offered and refused was recorded daily.

Experimental diets were formulated to meet NRC (2001) requirements for late gestation and early lacta- tion (Table 1). Basal prepartum and postpartum diets were mixed daily (model 3120 Reel Mixer, Kuhn North America, Brodhead, WI). Treatment premixes (Table 1) were prepared and included with the other ingredients during final mixing using a Data Ranger (American Calan Inc.). The amount of feed offered and refused was recorded daily. The amount offered to each cow was adjusted daily to provide a minimum $5 \%$ refusal. Samples of dietary ingredients and TMR were collected 3 times each week and DM was determined by drying in a forced-air oven $50^{\circ} \mathrm{C}$ for $48 \mathrm{~h}$. Samples were ground to pass through a 6 -mm screen, composited by week, and a subsample was ground to pass through a 1-mm screen. Samples were analyzed for concentrations of ash (AOAC International, 2000), N (Leco FP-528 Nitrogen Analyzer, St. Joseph, MO), ether extract, ADF (AOAC International, 2000), NDF (Van Soest et al., 1991), and minerals (AOAC International, 2000).

After calving, cows were milked 3 times daily at 0000, 0800, and $1600 \mathrm{~h}$. Milk weights were recorded electronically at each milking (Alpro, DeLaval, Kansas City, MO), totaled each day, and a weekly average was calculated. Milk samples were collected from 3 consecutive milkings each week. Samples were shipped for next-day delivery to Dairy One Cooperative (Ithaca, NY) for analysis of fat, protein, lactose, SNF, and MUN concentrations by mid-infrared spectrophotometric analysis using a Foss 4000 instrument (Foss North America, Eden Prairie, MN) as described by AOAC International (2000).

Body weight of cows was recorded on 3 consecutive days at the beginning of the trial and during wk 3 and 6 postpartum and once immediately after parturition. Access to water and feed was restricted until measurements were recorded immediately after the $0800 \mathrm{~h}$ milking. Body condition scores were assigned independently by 2 individuals when BW was recorded as described by Wildman et al. (1982). Energy balance was calculated according to NRC (2001) using data from wk 1, 3 , and 6 postpartum.

Two whole-blood samples were collected from the coccygeal vein at $0900 \mathrm{~h}$ once during wh $-3,-2$, and -1 prepartum, at calving, and wk $1,2,3$, and 6 postpartum. One sample was used for determination of serum glucose, urea N, total protein, albumin, creatinine, total bilirubin, aspartate aminotransferase, creatine kinase, gamma-glutamyltransferase, $\mathrm{Ca}, \mathrm{P}, \mathrm{Mg}, \mathrm{Na}, \mathrm{K}$, $\mathrm{Cl}$, bicarbonate, and anion gap using an Advia 1800 Clinical Chemistry System (Siemens Medical Solutions USA Inc., Malvern, PA). Serum was separated from the second sample and analyzed for NEFA concentrations using an enzymatic procedure (Waco Chemicals USA Inc., Richmond, VA). Blood ketone concentrations were determined using a Nova Max Ketone Strips and 
Table 1. Ingredient composition of experimental diets (\% of DM $)^{1}$

\begin{tabular}{|c|c|c|c|c|}
\hline \multirow[b]{2}{*}{ Ingredient } & \multicolumn{2}{|c|}{ Prepartum } & \multicolumn{2}{|c|}{ Postpartum } \\
\hline & $\mathrm{CON}$ & CMA & NBC & CMA \\
\hline Corn silage & 39.32 & 39.32 & 41.25 & 41.25 \\
\hline Alfalfa hay & 6.21 & 6.21 & & \\
\hline Ryegrass baleage & & & 5.38 & 5.38 \\
\hline Bermudagrass baleage & 5.17 & 5.17 & 1.79 & 1.79 \\
\hline Ground corn & 10.35 & 10.35 & 14.89 & 14.89 \\
\hline Cottonseed hulls ${ }^{2}$ & 0.46 & 0.41 & & 1.26 \\
\hline Citrus pulp & 7.24 & 7.24 & 5.38 & 5.38 \\
\hline Soybean hulls & 7.24 & 7.24 & 4.48 & 4.48 \\
\hline Brewers grains, wet & 8.28 & 8.28 & 11.66 & 11.66 \\
\hline Megalac $^{3}$ & & & 1.35 & 1.35 \\
\hline Biochlor $^{4}$ & 5.59 & 5.59 & & \\
\hline Soybean meal, $47.5 \%$ CP & 6.21 & 6.21 & 4.93 & 4.93 \\
\hline AminoPlus $^{5}$ & & & 1.79 & 1.79 \\
\hline Prolak $^{6}$ & & & 3.14 & 3.14 \\
\hline Urea & & & 0.18 & 0.18 \\
\hline Sodium bicarbonate & & & 1.26 & \\
\hline Magnesium oxide & 0.29 & 0.21 & 0.18 & 0.18 \\
\hline $\mathrm{CMA}^{7}$ & & 0.46 & & 0.39 \\
\hline Calcium carbonate $^{2}$ & 1.32 & 0.99 & 0.32 & \\
\hline Calcium monophosphate & 0.21 & 0.21 & 0.18 & 0.18 \\
\hline Salt & & & 0.63 & 0.63 \\
\hline Potassium carbonate $^{2}$ & & & 0.22 & 0.18 \\
\hline Potassium magnesium sulfate & 0.21 & 0.21 & 0.09 & 0.09 \\
\hline Zinpro Availa- $4^{8}$ & 0.08 & 0.08 & 0.04 & 0.04 \\
\hline Yeast culture $^{9}$ & 0.52 & 0.52 & 0.22 & 0.22 \\
\hline OmniGen-AF ${ }^{10}$ & 0.52 & 0.52 & 0.22 & 0.22 \\
\hline Vitamin E, 20,000 IU/454 g & 0.04 & 0.04 & 0.02 & 0.02 \\
\hline Monensin, $3 \mathrm{~g} / 454 \mathrm{~g}^{11}$ & 0.54 & 0.54 & 0.23 & 0.23 \\
\hline Trace mineral-vitamin premix ${ }^{12}$ & 0.20 & 0.20 & 0.14 & 0.14 \\
\hline
\end{tabular}

${ }^{1} \mathrm{CON}=$ control diet; $\mathrm{CMA}=$ supplemental calcareous marine algae; $\mathrm{NBC}=$ supplemental sodium bicarbonate.

${ }^{2}$ Ingredients were blended into a premix and added to the mixer before feeding.

${ }^{3}$ Calcium salts of long-chain FA, Arm Hammer Animal Nutrition, Church \& Dwight Co. Inc., Princeton, NY.

${ }^{4}$ Feed supplement providing a source of dietary anions, Arm Hammer Animal Nutrition, Church \& Dwight Co. Inc.

${ }^{5}$ Ruminally protected soybean meal, Ag Processing Inc., Omaha, NE.

${ }^{6}$ Marine and animal RUP supplement, H. J. Baker \& Bros. Inc., Westport, CT.

${ }^{7}$ Calcareous marine algae, Calmin, Celtic Sea Minerals, Cork, Ireland.

${ }^{8}$ Organic zinc, manganese, copper, and cobalt, Zinpro Corporation, Eden Prairie, MN.

${ }^{9}$ Diamond V XP Yeast Culture, Diamond V Mills, Cedar Rapids, IA.

${ }^{10}$ Immune modulator, Prince Agri Products Inc., Quincy, IL.

${ }^{11}$ Rumensin, Elanco Animal Health, Indianapolis, IN.

${ }^{12}$ Mineral-vitamin premix contained (DM basis) $26.1 \% \mathrm{Ca} ; 0.38 \% \mathrm{Mg} ; 1.76 \% \mathrm{~S} ; 144 \mathrm{mg} / \mathrm{kg}$ of Co; $9,523 \mathrm{mg} / \mathrm{kg}$ of $\mathrm{Cu} ; 1,465 \mathrm{mg} / \mathrm{kg}$ of Fe; $842 \mathrm{mg} / \mathrm{kg}$ of I; $28,617 \mathrm{mg} / \mathrm{kg}$ of Mn; $220 \mathrm{mg} / \mathrm{kg}$ of Se; $25,343 \mathrm{mg} / \mathrm{kg}$ of Zn; 4,210,830 $\mathrm{IU} / \mathrm{kg}$ of vitamin $\mathrm{A} ; 1,684,330 \mathrm{IU} / \mathrm{kg}$ of vitamin $\mathrm{D} ; 21,045 \mathrm{IU} / \mathrm{kg}$ of vitamin $\mathrm{E}$.

a Nova Max Plus reader (Nova Biomedical, Waltham, MA). Urine samples were also collected for analyses for $\mathrm{pH}$ and electrolyte concentrations.

Intake and production data were analyzed as repeated measures using PROC MIXED procedures of SAS (SAS Institute, Cary, NC). The model included lactation number, pre- and postpartum treatments, interaction of lactation number and pre- and postpartum treatment, interaction of pre- and postpartum treatments, week, interaction of prepartum treatment and week, interaction of postpartum treatment and week, as well as interaction of pre- and postpartum treatment by week and error. The first-order autoregressive covariance structure was used according to Littell et al. (1998). Genetic merit (PTA of multiparous cows and ETA of springing heifers) was included as a covariate for production variables. The interaction of lactation number and prepartum and postpartum treatment was not significant $(P>0.10)$ and was not included in the final data analysis. Daily DMI and milk yield were analyzed as repeated measures using the same model with DIM rather than week. Cow within treatment 
was used as the error term for testing prepartum and postpartum treatments and their interactions. Week or DMI was included as a repeated measure. Prepartum blood and urine metabolite data were analyzed using the same model as described above without effect of postpartum treatment and associated interactions or genetic merit covariate. Postpartum blood and urine metabolites were analyzed separately using the model described above without the genetic merit covariate.

\section{RESULTS AND DISCUSSION}

The chemical composition of the experimental diets is presented in Table 2. Nutrient concentrations were similar for prepartum diets and postpartum diets except that Na concentrations were greater for NBC than CMA postpartum, as expected. The DCAD $[(\mathrm{Na}+\mathrm{K})$ $-(\mathrm{Cl}+\mathrm{S})]$ of the diets was $-5.17,-3.99,35.58$, and $15.64 \mathrm{mEq} / 100 \mathrm{~g}$ for CON, CMA prepartum, NBC, and CMA postpartum, respectively.

Prepartum DMI was not different among treatments for CON and CMA and averaged 11.9 and 12.2 $\mathrm{kg} / \mathrm{d}$, respectively. Postpartum DMI, milk yield, and composition are presented in Table 3. No differences among treatments were observed in DMI, milk yield, percentage of milk fat, protein, and lactose. Milk protein yield was higher $(P=0.05)$ for the cows fed CMA prepartum compared with CON, at 1.09 and $1.02 \mathrm{~kg} / \mathrm{d}$ respectively. Interactions of prepartum treatment and week were observed for milk fat yield $(P=0.02$; Figure $1)$ and $\operatorname{ECM}(P=0.04$; Figure 2$)$ because of higher yields for cows fed CMA during wk 2 and 6 compared with CON. An interaction of prepartum treatment and week $(P=0.03)$ was observed for milk efficiency (ECM/DMI; Figure 3) because of lower efficiencies for cows fed CMA during wk 1 and 4 compared with CON; however efficiencies tended to reverse and tended to be slightly numerically higher for CMA compared with CON during wk 6 . Daily milk yield exhibited an interaction of postpartum treatment and DIM $(P=0.009)$, as milk yield was higher for NBC compared with CMA during 28 to 31 DIM but was not different during 1 to 27 or 32 to 42 DIM (Figure 4). No differences were observed among treatments in BW, BCS, or BW change throughout the trial. An interaction of postpartum treatment and week was observed for BCS $(P=0.01)$, because BCS decreased from wk 0 to 6 (3.27 to 3.11 , respectively) for cows fed CMA whereas BCS remained constant for CON: 3.23 at wk 0 and 3.22 at wk 6 .

Calculated energy balance postpartum was not different among treatments $(P>0.01)$ but exhibited a interaction of prepartum treatment and week postpartum $(P=0.03)$, as cows fed CON were in a greater energy balance deficiency wk 1 ( -10.0 compared with $-5.0 \mathrm{mcal} / \mathrm{d}$ for CON and CMA, respectively) but were more positive during wk 6 ( -0.5 compared with -2.4 Mcal/d for CON and CMA, respectively) compared with cows fed CMA prepartum. Efficiency of energy consumed used for milk production exhibited an interaction of prepartum treatment and week $(P=0.03$; data not presented) and was similar to that observed for milk efficiency (Figure 3).

Concentrations of select metabolites and minerals in serum and urine prepartum are presented in Table 4.

Table 2. Chemical composition of experimental diets fed prepartum and postpartum and supplemented with or without calcareous marine algae ${ }^{1}$

\begin{tabular}{lccccc}
\hline & \multicolumn{2}{c}{ Prepartum } & & \multicolumn{2}{c}{ Postpartum } \\
\cline { 2 - 3 } \cline { 5 - 6 } $\begin{array}{l}\text { Ingredient, \% of DM, } \\
\text { unless otherwise noted }\end{array}$ & CON & CMA & & NBC & CMA \\
\hline DM, \% & $43.8 \pm 3.3$ & $44.4 \pm 3.3$ & & $39.5 \pm 3.4$ & $39.7 \pm 3.3$ \\
$\mathrm{CP}$ & $16.6 \pm 0.5$ & $16.4 \pm 0.5$ & & $17.0 \pm 0.9$ & $16.9 \pm 0.9$ \\
$\mathrm{ADF}$ & $24.9 \pm 1.3$ & $24.3 \pm 1.9$ & & $24.1 \pm 1.7$ & $24.1 \pm 1.7$ \\
$\mathrm{NDF}$ & $41.6 \pm 1.4$ & $41.1 \pm 1.7$ & & $41.8 \pm 1.1$ & $40.8 \pm 2.4$ \\
$\mathrm{Ash}$ & $7.59 \pm 0.17$ & $7.65 \pm 0.19$ & & $8.90 \pm 0.53$ & $8.06 \pm 0.40$ \\
$\mathrm{Ca}$ & $1.08 \pm 0.05$ & $1.16 \pm 0.09$ & & $0.88 \pm 0.05$ & $0.86 \pm 0.08$ \\
$\mathrm{P}$ & $0.41 \pm 0.02$ & $0.41 \pm 0.01$ & & $0.48 \pm 0.02$ & $0.47 \pm 0.02$ \\
$\mathrm{Mg}$ & $0.40 \pm 0.02$ & $0.40 \pm 0.02$ & & $0.34 \pm 0.02$ & $0.34 \pm 0.03$ \\
$\mathrm{~K}$ & $1.26 \pm 0.04$ & $1.30 \pm 0.03$ & & $1.48 \pm 0.11$ & $1.39 \pm 0.11$ \\
$\mathrm{~S}$ & $0.35 \pm 0.03$ & $0.35 \pm 0.03$ & & $0.24 \pm 0.02$ & $0.25 \pm 0.04$ \\
$\mathrm{Na}$ & $0.14 \pm 0.02$ & $0.15 \pm 0.03$ & & $0.77 \pm 0.06$ & $0.34 \pm 0.07$ \\
$\mathrm{Cl}$ & $0.77 \pm 0.02$ & $0.78 \pm 0.06$ & & $0.74 \pm 0.06$ & $0.68 \pm 0.04$ \\
$\mathrm{DCAD},{ }^{2} \mathrm{mEq} / 100 \mathrm{~g}$ & -5.17 & -3.99 & & 35.58 & 15.64 \\
DCAD, ${ }^{3} \mathrm{mEq} / 100 \mathrm{~g}$ & 16.70 & 17.88 & & 50.58 & 31.27 \\
\hline
\end{tabular}

${ }^{1} \mathrm{CON}=$ control diet; $\mathrm{CMA}=$ supplemental calcareous marine algae; $\mathrm{NBC}=$ supplemental sodium bicarbonate.

${ }^{2}$ Calculated as $(\mathrm{Na}+\mathrm{K})-(\mathrm{Cl}+\mathrm{S})$.

${ }^{3}$ Calculated as $\mathrm{Na}+\mathrm{K}-\mathrm{Cl}$. 
Table 3. Dry matter intake and performance of cows fed diets CON or CMA prepartum with NBC or CMA postpartum ${ }^{1}$

\begin{tabular}{|c|c|c|c|c|c|c|c|c|}
\hline Item & $\mathrm{CON} / \mathrm{NBC}$ & $\mathrm{CMA} / \mathrm{NBC}$ & $\mathrm{CON} / \mathrm{CMA}$ & CMA/CMA & $\mathrm{SE}$ & \multicolumn{3}{|c|}{$P$-value } \\
\hline DMI, kg/d & 18.0 & 19.8 & 19.4 & 20.0 & 0.9 & 0.17 & 0.35 & 0.46 \\
\hline Fat, $\%$ & 4.02 & 3.96 & 4.01 & 4.24 & 0.25 & 0.73 & 0.59 & 0.54 \\
\hline $\mathrm{Fat}^{3}{ }^{3} \mathrm{~kg} / \mathrm{d}$ & 1.53 & 1.54 & 1.49 & 1.61 & 0.08 & 0.29 & 0.38 & 0.62 \\
\hline Protein, \% & 2.71 & 2.85 & 2.71 & 2.81 & 0.08 & 0.12 & 0.78 & 0.78 \\
\hline Lactose, $\mathrm{kg} / \mathrm{d}$ & 1.81 & 1.85 & 1.77 & 1.80 & 0.05 & 0.66 & 0.86 & 0.93 \\
\hline $\mathrm{SNF}, \%$ & 8.37 & 8.38 & 8.41 & 8.37 & 0.08 & 0.86 & 0.88 & 0.72 \\
\hline $\mathrm{SNF}, \mathrm{kg} / \mathrm{d}$ & 3.19 & 3.27 & 3.12 & 3.18 & 0.09 & 0.61 & 0.98 & 0.91 \\
\hline $3.5 \% \mathrm{FCM}^{3}, \mathrm{~kg} / \mathrm{d}$ & 41.3 & 41.9 & 40.2 & 42.6 & 1.6 & 0.27 & 0.66 & 0.75 \\
\hline $\mathrm{ECM},{ }^{3} \mathrm{~kg} / \mathrm{d}$ & 40.2 & 41.3 & 39.1 & 41.5 & 1.4 & 0.14 & 0.79 & 0.89 \\
\hline \multicolumn{9}{|l|}{ Efficiency } \\
\hline $\mathrm{FCM} / \mathrm{DMI}^{3}$ & 2.30 & 2.12 & 2.07 & 2.13 & 0.13 & 0.33 & 0.53 & 0.56 \\
\hline
\end{tabular}

${ }^{1} \mathrm{CON}=$ control diet; $\mathrm{CMA}=$ supplemental calcareous marine algae; $\mathrm{NBC}=$ supplemental sodium bicarbonate. Diets are written as prepartum diet/postpartum diet.

${ }^{2}$ Interaction of postpartum treatment and day $(P<0.05)$.

${ }^{3}$ Interaction of prepartum treatment and week $(P<0.05)$.

Prepartum serum Na was higher $(P=0.05)$ for $\mathrm{CON}$ compared with CMA, at 143.32 to $142.55 \mathrm{mEq} / \mathrm{L}$, respectively. Prepartum urine $\mathrm{pH}$ tended to be higher $(P$ $=0.09$ ) for CON compared with CMA, at 7.35 and 7.00, respectively. No differences were observed in the other metabolites and minerals. No interaction of treatment and week was observed for any variables prepartum.
Concentrations of select metabolites and minerals in serum and urine of cows postpartum are presented in Table 5. Interactions of prepartum and postpartum treatments were observed for serum urea $\mathrm{N}(P=0.01)$ and creatinine $(P=0.0005)$. Concentrations of serum urea $\mathrm{N}$ were highest for CON-NBC, CMA-CMA, intermediate for CON-CMA, and lowest for CMA-NBC,

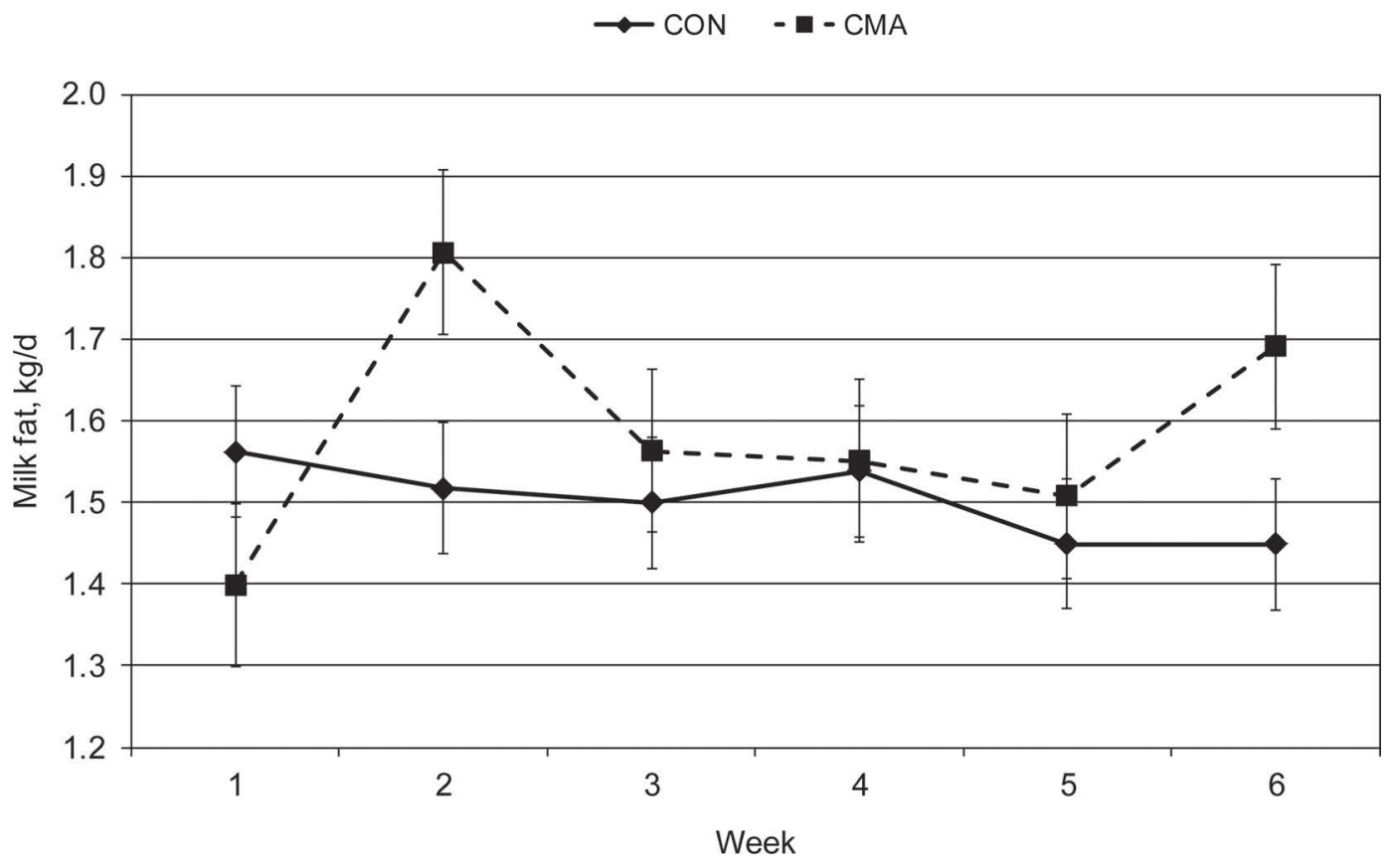

Figure 1. Interaction between prepartum treatments and weeks on milk fat yield $(P=0.02 ; \mathrm{CON}=$ control; CMA $=$ cows fed supplemental calcareous marine algae). 


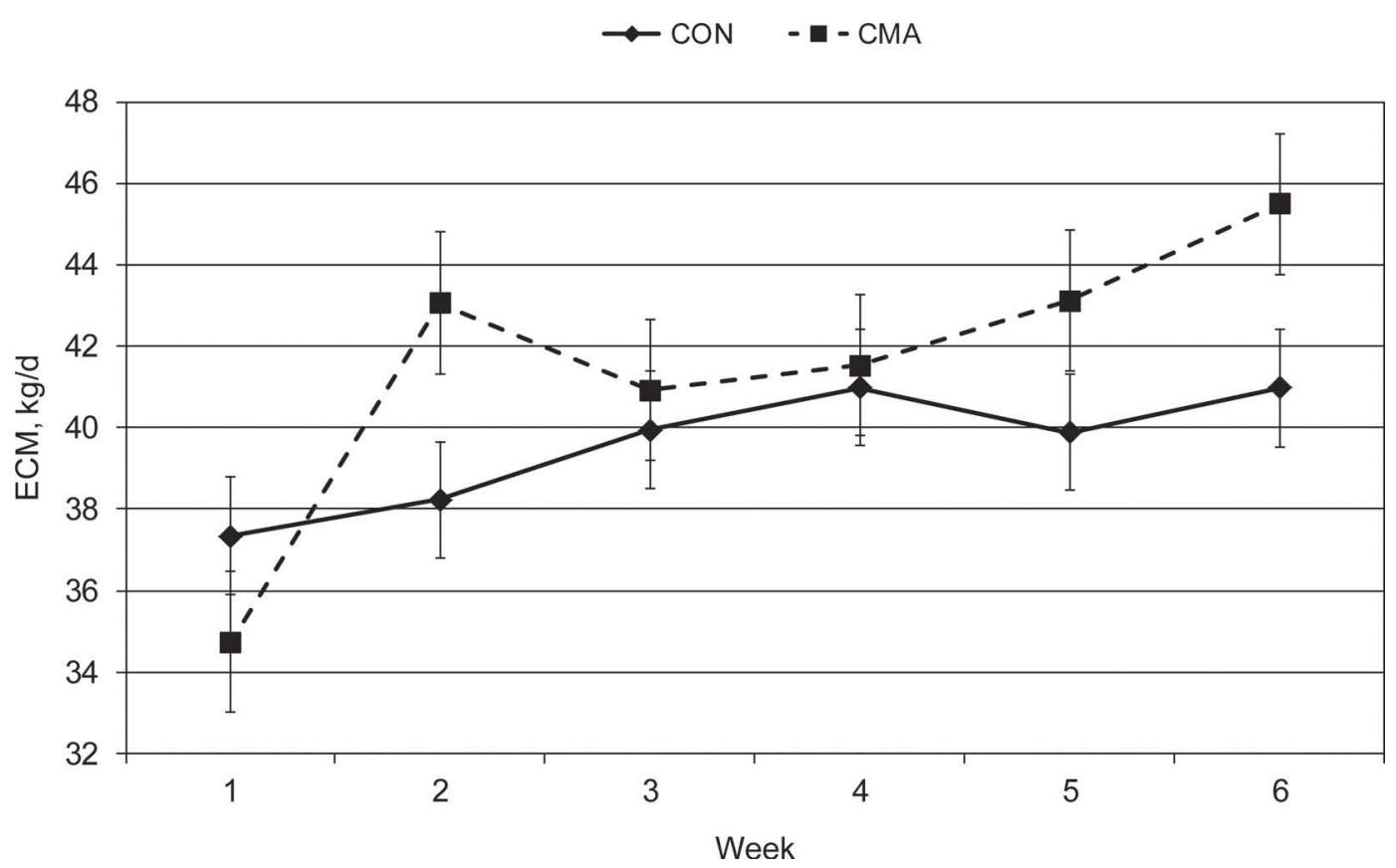

Figure 2. Interaction between prepartum treatments and weeks on ECM $(P=0.04 ; \mathrm{CON}=$ control; CMA $=$ cows fed supplemental calcareous marine algae).

at $12.18,11.70,11.20$, and $10.31 \mathrm{mg} / \mathrm{dL}$, respectively. Concentrations of creatinine were highest for CON$\mathrm{NBC}$ and CMA-CMA, intermediate for CMA-NBC, and lowest for CON-CMA, at 0.77, 0.77, 0.70, and 0.65 $\mathrm{mg} / \mathrm{dL}$, respectively. Postpartum concentrations of se- rum Na were higher $(P=0.02)$ for NBC compared with CMA, at 140.60 to $139.81 \mathrm{mEq} / \mathrm{L}$, respectively. An interaction of prepartum and postpartum treatments $(P$ $=0.04$ ) was observed for urine Na concentration, which was higher for CON-NBC and CMA-NBC compared

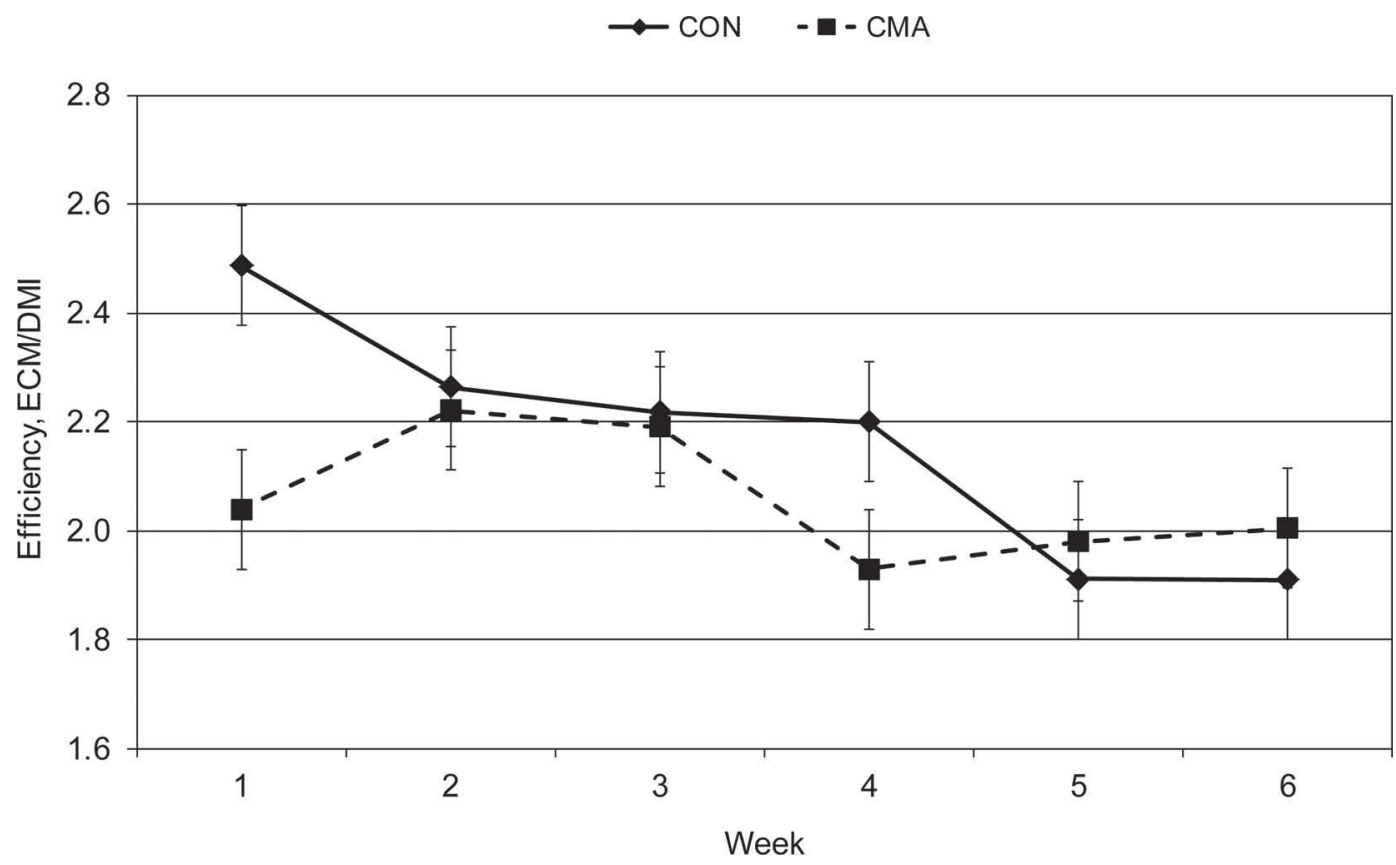

Figure 3. Interaction between prepartum treatments and weeks on milk efficiency, ECM/DMI $(P=0.03 ; \mathrm{CON}=$ control; CMA $=$ cows fed supplemental calcareous marine algae). 


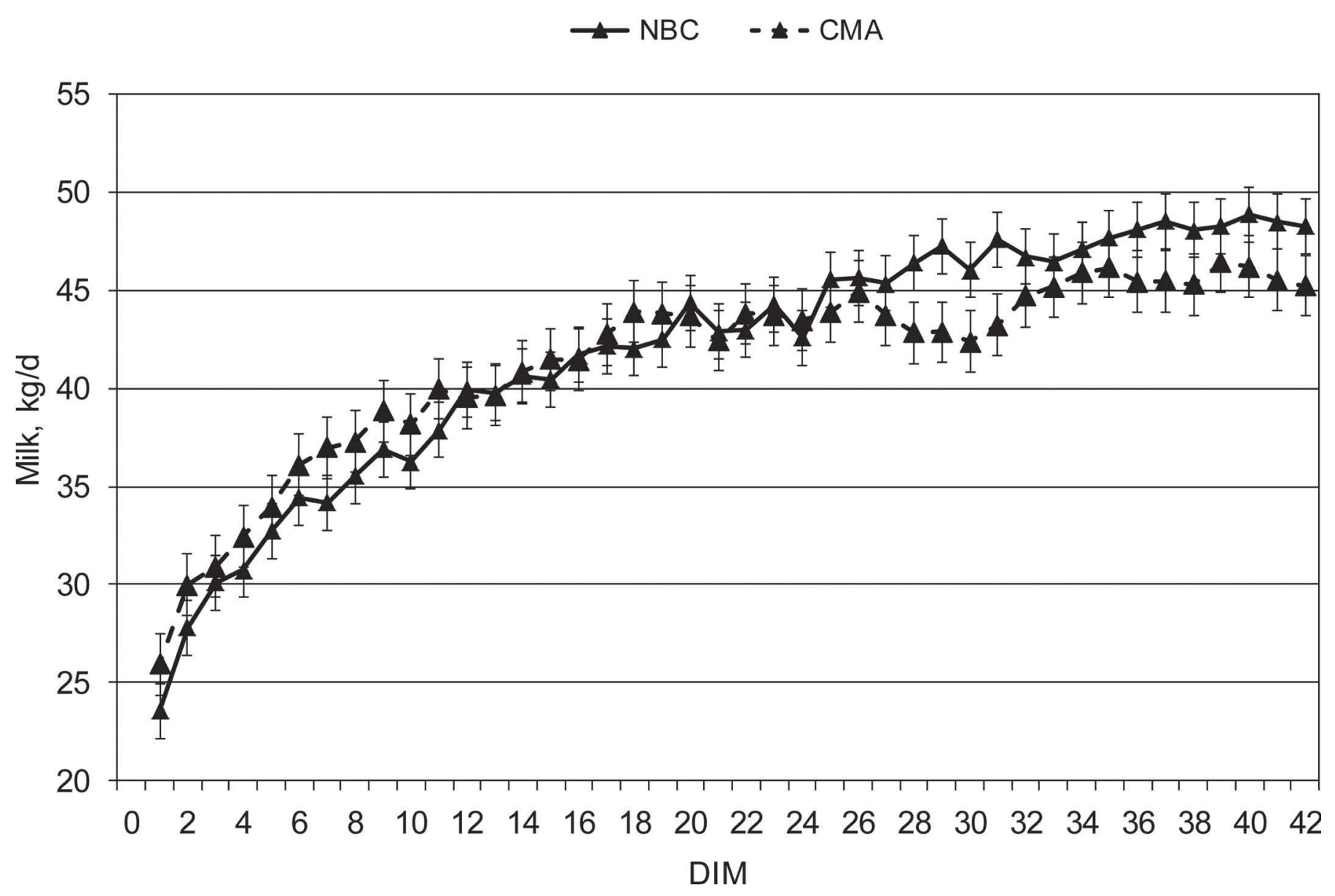

Figure 4. Interaction between postpartum treatment and DIM on milk yield $(P=0.009$; CMA $=$ cows fed supplemental calcareous marine algae; NBC = supplemental sodium bicarbonate).

with CON-CMA and CMA-CMA, at 121.21, 105.43, 41.24, and $59.55 \mathrm{mmol} / \mathrm{L}$, respectively. Postpartum urine $\mathrm{K}(P=0.003)$ was higher for the cows fed CMA postpartum compared with NBC, at 155.60 and 118.40 $\mathrm{mmol} / \mathrm{L}$, respectively. No interaction of treatment and week was observed for any variables postpartum.

Cows fed diets supplemented with CMA prepartum had higher milk protein yield and yields of milk fat and ECM during wk 2 and 6 compared with CON. The lower energy balance observed for CON during wk 1 suggests that cows fed CMA prepartum transitioned better into lactation, which may partially explain the differences in milk component yield. Although not significantly different, the DMI of cows fed supplemental CMA prepartum was numerically higher compared with CON before parturition and postpartum (Figure 5). Despite not being different, the small improvement would have provided additional nutrients which would have maintained a more positive energy balance prepartum, which is consistent with the energy balance data. In a previous trial, Bernard et al. (2014) reported increased DMI for cows fed diets supplemented with sodium bicarbonate compared with CMA. No differences were observed in milk yield, but efficiency of milk production was higher for cows fed CMA compared with those fed sodium bicarbonate during the last $3 \mathrm{wk}$ of the trial.

Calitz (2009) did not observe any difference in DMI, milk yield, or composition of cows fed a diet supplemented with CMA, sodium bicarbonate, or combinations of both. In contrast, Beya (2007) reported improved milk yield and milk fat percentage for cows fed diets supplemented with CMA compared with sodium bicarbonate or the control diet without supplemental buffers.

Hu and Murphy (2004) conducted a meta-analysis of trials examining the response of lactating cows to increasing dietary DCAD and concluded that maximum DMI and milk yield occurred when dietary DCAD $(\mathrm{Na}+\mathrm{K}-\mathrm{Cl})$ increased to 34 and $40 \mathrm{mEq} / 100 \mathrm{~g}$ of 
Table 4. Concentrations of select metabolites and minerals in serum and urine prepartum of cows fed diets supplemented with or without calcareous marine algae

\begin{tabular}{|c|c|c|c|c|}
\hline \multirow[b]{2}{*}{ Item } & \multicolumn{2}{|c|}{ Treatment $^{1}$} & \multirow[b]{2}{*}{$\mathrm{SE}$} & \multirow{2}{*}{$\frac{P \text {-value }}{\text { Treatmen }}$} \\
\hline & $\mathrm{CON}$ & CMA & & \\
\hline \multicolumn{5}{|l|}{ Serum } \\
\hline NEFA, mEq/L & 0.82 & 0.83 & 0.16 & 0.97 \\
\hline Ketone, $\mathrm{mmol} / \mathrm{mL}$ & 0.38 & 0.37 & 0.04 & 0.69 \\
\hline Total protein, $\mathrm{g} / \mathrm{dL}$ & 6.51 & 6.44 & 0.12 & 0.66 \\
\hline Albumin, g/dL & 3.50 & 3.48 & 0.06 & 0.77 \\
\hline Globulin, g/dL & 3.02 & 3.00 & 0.14 & 0.91 \\
\hline Urea $\mathrm{N}, \mathrm{mg} / \mathrm{dL}$ & 13.92 & 13.51 & 0.45 & 0.49 \\
\hline Creatinine, $\mathrm{mg} / \mathrm{dL}$ & 0.90 & 0.91 & 0.03 & 0.88 \\
\hline BUN/creatinine & 15.94 & 15.43 & 0.72 & 0.60 \\
\hline Total bilirubin, $\mathrm{mg} / \mathrm{dL}$ & 0.17 & 0.17 & 0.05 & 0.94 \\
\hline Glucose, $\mathrm{mg} / \mathrm{dL}$ & 73.09 & 74.60 & 3.29 & 0.73 \\
\hline Aspartate aminotransferase, U/L & 75.46 & 74.93 & 4.68 & 0.93 \\
\hline Creatinine kinase, U/L & 210.79 & 189.92 & 33.57 & 0.79 \\
\hline Gamma-glutamyltransferase, IU/L & 13.80 & 13.02 & 1.30 & 0.64 \\
\hline $\mathrm{Ca}, \mathrm{mg} / \mathrm{dL}$ & 9.21 & 9.08 & 0.11 & 0.31 \\
\hline $\mathrm{P}, \mathrm{mg} / \mathrm{dL}$ & 6.09 & 6.28 & 0.15 & 0.31 \\
\hline $\mathrm{Mg}, \mathrm{mg} / \mathrm{dL}$ & 2.42 & 2.36 & 0.05 & 0.36 \\
\hline $\mathrm{Na}, \mathrm{mEq} / \mathrm{L}$ & 143.32 & 142.55 & 0.29 & 0.05 \\
\hline $\mathrm{K}, \mathrm{mEq} / \mathrm{L}$ & 4.64 & 4.70 & 0.06 & 0.49 \\
\hline $\mathrm{Cl}, \mathrm{mEq} / \mathrm{L}$ & 104.55 & 104.86 & 0.43 & 0.58 \\
\hline Bicarbonate, mmol/L & 28.15 & 27.73 & 0.43 & 0.45 \\
\hline Anion gap, mmol/L & 14.75 & 15.52 & 1.04 & 0.50 \\
\hline \multicolumn{5}{|l|}{ Urine } \\
\hline $\mathrm{pH}$ & 7.35 & 7.00 & 0.16 & 0.09 \\
\hline $\mathrm{Na}, \mathrm{mmol} / \mathrm{L}$ & 38.25 & 25.30 & 5.97 & 0.10 \\
\hline $\mathrm{K}, \mathrm{mmol} / \mathrm{L}$ & 144.91 & 137.86 & 11.49 & 0.64 \\
\hline $\mathrm{Cl}, \mathrm{mmol} / \mathrm{L}$ & 125.40 & 127.00 & 10.58 & 0.91 \\
\hline
\end{tabular}

${ }^{1} \mathrm{CON}=$ control diet and $\mathrm{CMA}=$ supplemental calcareous marine algae.

DMI, respectively. Similar results were also reported by Wildman et al. (2007) when postpartum DCAD was increased from 14.2 to $38.7 \mathrm{mEq} / 100 \mathrm{~g}$. In the current trial, the inclusion of CMA postpartum was as effective as NBC for maintaining milk yield and composition even though diets containing CMA had lower DCAD compared with $\mathrm{NBC}$, at 15 and $36 \mathrm{mEq} / 100 \mathrm{~g}$, respectively. The diets in the current trial were based primarily on corn silage and supplemented with finely ground corn and would be expected to benefit from increasing dietary DCAD. Beya (2007) reported greater milk yield for cows fed CMA compared with sodium bicarbonate and attributed the improvements to the slow-release buffer effect and higher bioavailability of the $\mathrm{Ca}$, which may explain the similar performance from CMA at lower DCAD level compared with NBC in our study.

Serum bicarbonate and mineral concentrations were not different among treatments, except that $\mathrm{Na}$ was higher for cows fed CON prepartum and for cows fed NBC postpartum compared with those fed CMA. The reason for the slightly higher serum $\mathrm{Na}$ concentrations prepartum is not clear, as dietary concentrations of $\mathrm{Na}$ were similar for both CON and CMA. The small difference is not likely of biological significance. The increased concentrations of $\mathrm{Na}$ in serum and urinary observed with NBC reflects the higher dietary Na concentrations and intake for cows fed NBC compared with CMA, 0.77 and $0.34 \%$ of DM, respectively. The increase in postpartum concentrations of $\mathrm{K}$ observed with CMA compared with $\mathrm{NBC}$ was not related to dietary concentrations or intake. This difference may reflect increased excretion by the kidneys to maintain electrostatic balance. Urinary $\mathrm{pH}$ tended to be higher prepartum for cows fed CON compared with CMA, but no differences were observed postpartum. $\mathrm{Hu}$ and Murphy (2004) reported a linear increase in blood bicarbonate concentrations as DCAD increased, although concentrations of $\mathrm{Na}$ and $\mathrm{K}$ were not altered. $\mathrm{Hu}$ and Murphy (2004) also reported increased urinary excretion of $\mathrm{Na}$ and $\mathrm{K}$ as DCAD increased and proposed that the increased excretion prevented any increase in blood concentrations.

\section{CONCLUSIONS}

Feeding CMA prepartum did not alter prepartum DMI, but supported higher milk protein yield postpartum and maintained similar DMI, milk yield, and percentage of fat, lactose, and SNF as CON. Changes in serum and urine metabolite concentrations primarily 


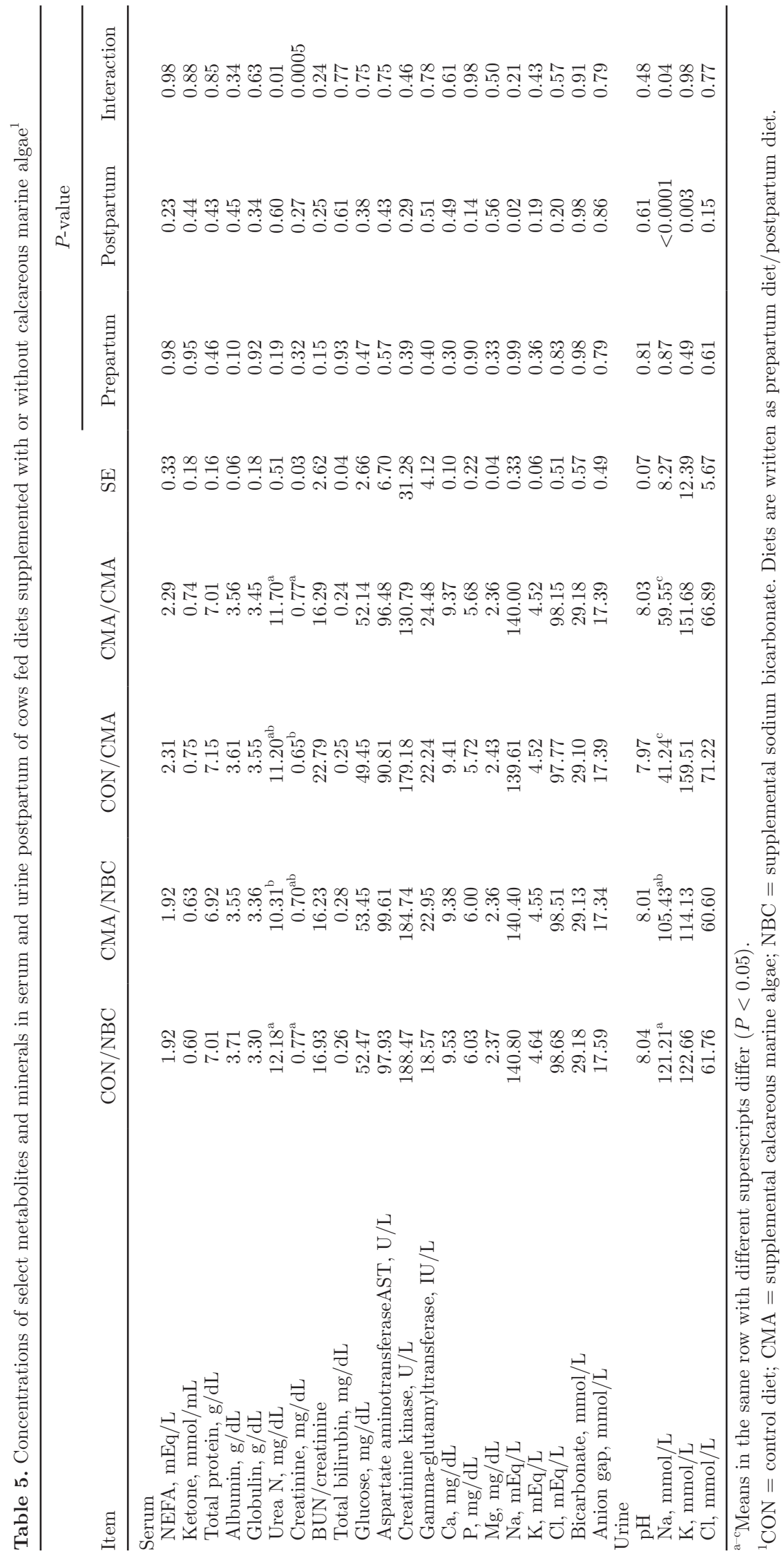




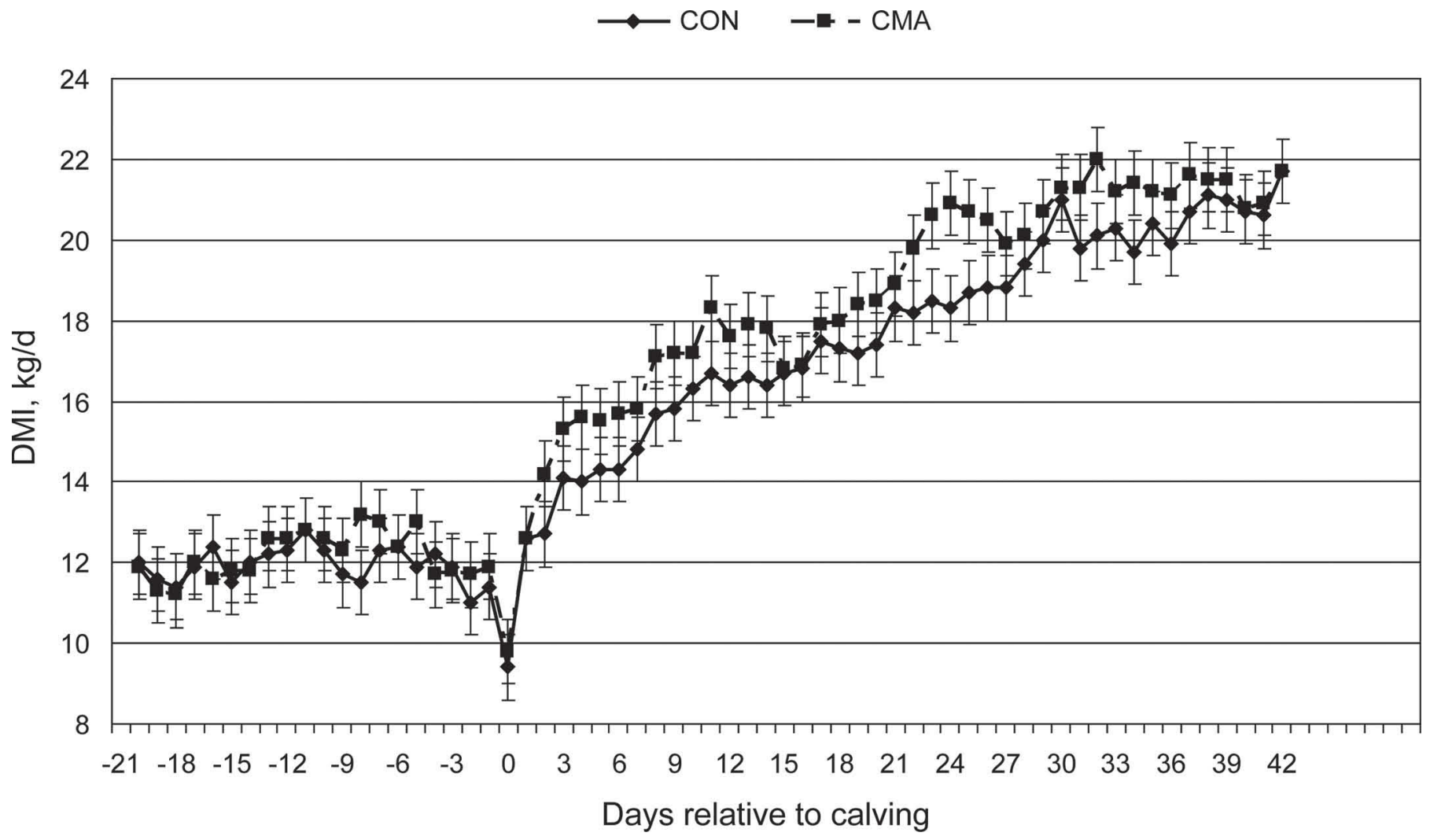

Figure 5. Daily DMI relative to calving $(\mathrm{CON}=$ no supplemental calcareous marine algae prepartum; CMA = supplemental calcareous marine algae prepartum). Interaction of prepartum treatment and week $(P=0.56)$.

reflected differences in dietary mineral supplementation. When fed postpartum, no differences were observed between CMA and NBC for DMI and milk yield and composition.

\section{ACKNOWLEDGMENTS}

The authors thank Celtic Sea Minerals for financial support of this project. Appreciation is extended to the Vic Cornett and the staff of the Dairy Research Center (Tifton, GA) for assistance with animal care during the trial and to Melissa Tawzer and Anita Merrill (University of Georgia, Tifton) for assistance with laboratory analysis.

\section{REFERENCES}

AOAC International. 2000. Official Methods of Analysis. 17th ed. AOAC International, Arlington, VA.

Aslam, M. N., J. M. Kreider, T. Paruchuri, N. Bhagavathula, M. DaSilva, R. F. Zernicke, S. A. Goldstein, and J. Varani. 2010. A mineral-rich extract from the red marine algae Lithothamnion calcareum preserves bone structure and function in female mice on a western-style diet. Calcif. Tissue Int. 86:313-324.

Bernard, J. K., J. W. West, N. Mullis, Z. Wu, and S. J. Taylor. 2014. Evaluation of calcareous marine algae supplements on production and metabolic parameters of early lactation dairy cows. Prof. Anim. Sci. 30:649-656.

Beya, M. M. 2007. The effect of buffering dairy cows diets with limestone, Acid Buf or sodium bicarbonate on production response and rumen metabolism. MS Thesis. Stellenbosch Univ., Matieland, South Africa.

Block, E. 1984. Manipulating dietary anions and cations for prepartum dairy cows to reduce incidence of milk fever. J. Dairy Sci. 67:2939-2948.

Calitz, T. 2009. The effect of Acid Buf and combinations of Acid Buf and sodium bicarbonate in dairy cow diets on production response and rumen parameters. MS Thesis. Stellenbosch Univ., Matieland, South Africa.

Curtis, C. R., H. N. Erb, C. J. Sniffen, R. D. Smith, and D. S. Kronfeld. 1985. Path analysis of dry period nutrition, postpartum metabolic and reproductive disorders, and mastitis in Holstein cows. J. Dairy Sci. 68:2347-2360.

Curtis, C. R., H. N. Erb, C. J. Sniffen, R. D. Smith, P. A. Powers, M. C. Smith, M. E. White, R. B. Hillman, and E. J. Pearson. 1983 Association of parturient hypocalcemia with eight periparturient disorders in Holstein cows. J. Am. Vet. Med. Assoc. 183:559-561.

Goff, J. P., R. L. Horst, F. J. Mueller, J. K. Miller, G. A. Kiess, and H. H. Dowlen. 1991. Addition of chloride to a prepartal diet high in cations increases 1, 25-dihydroxyvitamin d response to hypocalcemia preventing milk fever. J. Dairy Sci. 74:3863-3871.

Hu, W., and M. R. Murphy. 2004. Dietary cation-anion difference effects on performance and acid-base status of lactating dairy cows: A meta-analysis. J. Dairy Sci. 87:2222-2229.

Littell, R. C., P. R. Henry, and C. A. Ammerman. 1998. Statistical analysis of repeated measures data using SAS procedures. J. Anim. Sci. 76:1216-1231. 
Mesgaran, M. D., J. Amini, and M. Paktinat. 2013. In vitro usage of various non-organic compounds to subdue acidogenic value and enhance the fermentation of alfalfa hay based diets by mixed rumen microbiota. Int. J. Livest. Prod. 4:165-171.

NRC. 2001. Nutrient Requirements of Dairy Cattle. 7th rev. ed. Natl. Acad. Sci., Washington DC.

Oetzel, G. R., J. D. Olson, C. R. Curtis, and M. J. Fettman. 1988. Ammonium chloride and ammonium sulfate for prevention of parturient paresis in dairy cows. J. Dairy Sci. 71:3302-3309.

Slevin, M. M., P. J. Allsopp, P. J. Magee, M. P. Bonham, V. R. Naughton, J. J. Strain, M. E. Duffy, J. M. Wallace, and E. M. Mc Sorley. 2014. Supplementation with calcium and short-chain fructo-oligosaccharides affects markers of bone turnover but not bone mineral density in postmenopausal women. J. Nutr. 144:297-304.

Van Soest, P. J., J. B. Robertson, and B. A. Lewis. 1991. Methods for dietary fiber, neutral detergent fiber, and nonstarch polysaccharides in relation to animal nutrition. J. Dairy Sci. 74:3583-3597.
West, J. W., K. D. Haydon, B. G. Mullinix, and T. G. Sandifer. 1992. Dietary cation-anion balance and cation source effects on production and acid-base status of heat-stressed cows. J. Dairy Sci. $75: 2776-2786$.

West, J. W., B. G. Mullinix, and T. G. Sandifer. 1991. Changing dietary electrolyte balance for dairy cows in cool and hot environments. J. Dairy Sci. 74:1662-1674.

Wildman, C. D., J. W. West, and J. K. Bernard. 2007. Effect of dietary cation-anion difference and dietary crude protein on milk yield, acid-base chemistry, and rumen fermentation. J. Dairy Sci. 90:4693-4700.

Wildman, E. E., G. M. Jones, P. E. Wagner, R. L. Boman, H. F. Troutt Jr., and T. N. Lesch. 1982. A dairy cow body condition scoring system and its relationship to selected production characteristics. J. Dairy Sci. 65:495-501. 